\title{
Neonatal hyper- and hypothyroidism alter the myoglobin gene expression program in adulthood
}

\author{
K. de Picoli Souza ${ }^{1}$ and M.T. Nunes ${ }^{2}$ \\ ${ }^{1}$ Faculdade de Ciências Biológicas e Ambientais, Universidade Federal da Grande Dourados, Dourados, MS, Brasil \\ ${ }^{2}$ Departamento de Fisiologia e Biofísica, Instituto de Ciências Biológicas, Universidade de São Paulo, São Paulo, SP, Brasil
}

\begin{abstract}
Myoglobin acts as an oxygen store and a reactive oxygen species acceptor in muscles. We examined myoglobin mRNA in rat cardiac ventricle and skeletal muscles during the first 42 days of life and the impact of transient neonatal hypo- and hyperthyroidism on the myoglobin gene expression pattern. Cardiac ventricle and skeletal muscles of Wistar rats at 7-42 days of life were quickly removed, and myoglobin mRNA was determined by Northern blot analysis. Rats were treated with propylthiouracil $(5-10 \mathrm{mg} / 100 \mathrm{~g})$ and triiodothyronine $(0.5-50 \mu \mathrm{g} / 100 \mathrm{~g})$ for 5,15 , or 30 days after birth to induce hypo- and hyperthyroidism and euthanized either just after treatment or at 90 days. During postnatal $(P)$ days $7-28$, the ventricle myoglobin mRNA remained unchanged, but it gradually increased in skeletal muscle (12-fold). Triiodothyronine treatment, from days P0-P5, increased the skeletal muscle myoglobin mRNA 1.5- to 4.5-fold; a 2.5-fold increase was observed in ventricle muscle, but only when triiodothyronine treatment was extended to day P15. Conversely, hypothyroidism at P5 markedly decreased $(60 \%)$ ventricular myoglobin mRNA. Moreover, transient hyperthyroidism in the neonatal period increased ventricle myoglobin mRNA (2-fold), and decreased heart rate (5\%), fast muscle myoglobin mRNA (30\%) and body weight (20\%) in adulthood. Transient hypothyroidism in the neonatal period also permanently decreased fast muscle myoglobin mRNA (30\%) and body weight (14\%). These results indicated that changes in triiodothyronine supply in the neonatal period alter the myoglobin expression program in ventricle and skeletal muscle, leading to specific physiological repercussions and alterations in other parameters in adulthood.
\end{abstract}

Key words: Muscle; Thyroid hormone; Long-term consequences; Early postnatal life

\section{Introduction}

Myoglobin $(\mathrm{Mb})$ is an important intracellular oxygen $\left(\mathrm{O}_{2}\right)$ binding protein that is highly expressed in cardiac and skeletal muscles (1), and highly conserved among species (2). The oxymyoglobin structure reveals its role as a muscular store of $\mathrm{O}_{2}$ (3); additionally, this protein functions as a scavenger of reactive species of $\mathrm{O}_{2}$ and nitric oxide (4). Although Mb plays an essential role in oxidative metabolism, Mb-knockout mice (myo-/-) survive as a consequence of several adjustments in cardiac metabolism (5). Increased capillary density, coronary blood flow, and elevated hematocrit combine to assure an increase in the $\mathrm{PO}_{2}$ gradient in mitochondria, similar to effects that occur in response to the hypoxia observed in exercise and pregnancy $(6,7)$.

Thyroid hormone ( $\mathrm{TH}$ ) was shown to upregulate $\mathrm{Mb}$ gene expression in adult rats $(8,9)$, but, there is scarce information on this effect in the postnatal period, particularly in the first month of life, when skeletal and cardiac muscles are not yet completely mature. In 1996, Garry et al. (10) demonstrated a progressive enhancement of $\mathrm{Mb}$ expression following birth in mice, which paralleled the expression of several proteins associated with the phenotype of mature skeletal muscle. On the other hand, the pattern of $\mathrm{Mb}$ gene expression in cardiac muscle in the period of early postnatal development has not yet been examined and deserves to be evaluated.

Cardiac and skeletal muscles are still immature at birth. Their postnatal development includes the transition of the expression pattern of many genes and replacement of fetal contractile and metabolic proteins to the adult isoforms (11-13). TH plays an important role in the establishment of these changes, some of which occur in parallel with the increase in serum $\mathrm{TH}$ concentration normally observed during that period (14).

Correspondence: M.T. Nunes, Departamento de Fisiologia e Biofísica, Instituto de Ciências Biológicas, USP, 05508-900 São Paulo, SP, Brasil. Fax: +55-11-3091-7285. E-mail: mtnunes@icb.usp.br 
In adult life, the major effects of hypo- and hyperthyroidism on skeletal and cardiac muscles are abolished when the subjects return to the euthyroid state. However, in the early postnatal period, when the pattern of expression of many genes is being established, alterations in thyroid function can lead to modifications in the gene expression programs of adulthood (15).

In this study, we evaluated Mb mRNA expression in rat cardiac and skeletal muscles during postnatal development and after induction of hyper- and hypothyroidism in the first 2 weeks of life. We also investigated the effects of inducing hypo- and hyperthyroidism from postnatal days zero (P0) to 30 (P30) on Mb gene expression in heart ventricle and skeletal muscles, ventricle weight, heart rate $(\mathrm{HR})$ and arterial blood pressure (ABP) in adulthood.

\section{Material and Methods}

\section{Animals and treatments}

Animal care and experimental procedures performed in this study followed the ethical principles for animal research adopted by Brazil's National Council of Animal Experimentation (CONCEA) and were approved by the Ethics Committee for Animal Research (CEEA) of the Instituto de Ciências Biomédicas, Universidade de São Paulo.

Pregnant Wistar rats were obtained from the breeding colony of the Instituto de Ciências Biomédicas. They had free access to commercial chow and tap water in a temperature-controlled room $\left(23 \pm 1^{\circ} \mathrm{C}\right)$ with a 12 -h lightdark cycle (lights on at 7:00 am). Newborn male Wistar rats weighing approximately $6 \mathrm{~g}$ were used in the study. In each group, treatment began on the first postnatal day (P1) after birth (P0). Each litter consisted of approximately eight rats per dam, and animals were maintained under controlled conditions as described above from days P1 through P42. Rats were randomly assigned to the following three experiments: i) Mb gene expression in heart ventricle and skeletal muscles was determined during postnatal development on days P7, P14, P21, P28, P35, and P42 in groups consisting of 12 rats each. ii) The effect of $\mathrm{TH}$ on the expression of Mb mRNA in heart ventricle and skeletal muscles was determined during the first 2 weeks of life. Newborn rats were assigned to groups of 6 rats each for subcutaneous (sc) injection of $0.5,1.0,1.5,2.0,4.0$, or $50.0 \mu \mathrm{g} / 100 \mathrm{~g}$ body weight (BW) triiodothyronine $\left(\mathrm{T}_{3}\right.$; Sigma, USA; Hyper-5 group), groups of 12 rats each for $s c$ injection of 5 or $10 \mathrm{mg} / 100 \mathrm{~g} \mathrm{BW}$ propylthiouracil (PTU; Sigma; Hypo-5 group), or saline $(0.9 \% \mathrm{NaCl}$; Control- 5 group), for 5 days beginning on P1. Other groups of 12 newborn rats each were treated with sc injection of $4 \mu \mathrm{g} \mathrm{T}_{3} /$ 100 g BW (Hyper-15 group), 5 mg PTU/100 g BW (Hypo15 group), or saline (Control-15 group), for 15 days beginning on $\mathrm{P} 1$. The lactating dams of the Hypo-5 and Hypo-15 groups were also treated with PTU $(5 \mathrm{mg} / 100 \mathrm{~g}$ $\mathrm{BW}$ ) during the lactation period, to avoid $\mathrm{T}_{3}$ transfer to pups through milk. iii) Mb gene expression programming in heart ventricle and skeletal muscles was evaluated after induction of transient postnatal hyperthyroidism (HyperPNT) or hypothyroidism (HypoPNT). Newborn rats were exposed to $\mathrm{T}_{3}(4 \mu \mathrm{g} / 100 \mathrm{~g} \mathrm{BW}), \mathrm{PTU}$ (5 mg/100 g BW), or saline by sc injection for 30 days beginning at birth (P1). After this period, the treatments were stopped, and the animals were followed until they were 90 days old. They constituted the HyperPNT and HypoPNT groups. These animals were anesthetized, killed, and the repercussions of HyperPNT or HypoPNT induction on Mb gene expression, ventricular/ body weight ratio, $\mathrm{HR}$ and $\mathrm{ABP}$ were evaluated. Euthyroid animals were used as controls (Control-90 group). Each group consisted of 12 rats.

For the hormonal treatments, $100 \mu \mathrm{g} \mathrm{T}_{3}$ was dissolved in $2 \mathrm{~N} \mathrm{NaOH}(\sim 20 \mu \mathrm{L})$, diluted with $0.9 \% \mathrm{NaCl}$ to reach the concentrations used in the study, and adjusted to $\mathrm{pH} 7.4$. The animals were fasted for $2 \mathrm{~h}$, anesthetized with ketamine and xylazine (100 and $10 \mathrm{mg} / \mathrm{kg} \mathrm{BW}$, respectively) and killed by decapitation, after the specified periods of treatment. Handling of the offspring during the treatment period was performed by the same person throughout the experiment. A heat lamp was used to avoid cool-down.

Heart ventricle and skeletal muscles were quickly removed under aseptic conditions, for total RNA extraction as described previously (8). In experiments I and II, the skeletal muscle sample used was representative of the whole distal hind limb muscle, whereas in experiment III, the fast extensor digitalis longus (EDL) and slow soleus muscles were used.

To check the efficiency of the $\mathrm{T}_{3}$ and PTU treatments, heart ventricle weight and the day on which pups opened their eyes (DEO) were determined. Blood samples were also collected to evaluate thyroxine $\left(T_{4}\right)$ serum concentrations by radioimmunoassay (RIA; Diagnostic Products Corporation, UK), using a standard curve prepared with different concentrations of $\mathrm{T}_{4}$ in $\mathrm{TH}$-free rat serum. Intraand interassay coefficients of variation for the $\mathrm{T}_{4}$ RIA were $3-10 \%$, and $4.6-10 \%$, and $5.0-6.5 \%$ and $4.2-6.0 \%$, for the $\mathrm{T}_{3} \mathrm{RIA}$, respectively.

The most effective $T_{3}$ dose in inducing $M b$ gene expression in both tissues was $4 \mu \mathrm{g} / 100 \mathrm{~g} \mathrm{BW}$, a dose 13-times higher than the physiological replacement dose of $\mathrm{T}_{3}$, which is postulated to be $0.3 \mu \mathrm{g} / 100 \mathrm{~g} \mathrm{BW}(15,16)$, but lower than those used in similar studies (17). The PTU dose chosen to evaluate the effects of long-term hypothyroidism (15 and 30 day-treatment) was $5 \mathrm{mg} /$ $100 \mathrm{~g} \mathrm{BW}$, a dose equivalent to half of those used in comparable studies $(11,18)$.

\section{Total RNA extraction and Northern blot analysis}

Total RNA was isolated using the acid guanidinium thiocyanate-phenol-chloroform extraction method and quantified by absorbance at $260 \mathrm{~nm}$. Six micrograms of total RNA samples were denatured with formaldehydeformamide, electrophoresed in $1 \%$ agarose gels containing 
2.2 M formaldehyde in $1 \times 3$-n-morpholino-propanesulfonic acid (MOPS) buffer and blotted onto a nylon membrane (Nylon-1 membrane, Gibco BRL, USA) by neutral capillary transfer. The cross-linking of the RNA to the membrane was carried out at $80^{\circ} \mathrm{C}$ for $2 \mathrm{~h}$ in a vacuum oven, and prehybridized in $50 \%$ formamide hybridization solution and $100 \mu \mathrm{g} / \mathrm{mL}$ denatured salmon sperm DNA at $42^{\circ} \mathrm{C}$ for $4 \mathrm{~h}$. Subsequently, the membrane was probed with a ${ }^{32} \mathrm{P}$-labeled rat $\mathrm{Mb}$ cDNA by random priming (Random Primers DNA Labeling System kit, Gibco BRL) for $16 \mathrm{~h}$ at $42^{\circ} \mathrm{C}$. The membrane was washed under high stringency conditions and subjected to autoradiography and quantified by phosphor imaging, using the ImageQuant software (Molecular Dynamics, USA). All blots were stripped and rehybridized with a ${ }^{32} \mathrm{P}$-labeled RNA probe specific for the 18 s ribosomal subunit (18s rRNA), synthesized by in vitro transcription (Maxi Script in vitro transcription kit, Ambion, USA), to correct for the variability in RNA loading. The results are reported as means \pm SE of $\mathrm{Mb}$ mRNA/18S rRNA ratio.

\section{$H R$ and $A B P$ determination}

Animals in the Control-90, HyperPNT, and HypoPNT groups were maintained in a chamber at $45^{\circ} \mathrm{C}$ for $5 \mathrm{~min}$. After this period, they were restrained in acrylic cylinders, and their HR and systolic arterial pressure (SBP) were measured with a tail-cuff phethysmograph, an indirect method for measuring blood pressure (Kent Scientific USA). Data were collected after the animals had been subjected to the same procedure 3 times, at approximately the same time of day, in the previous weeks.

\section{Statistical analysis}

The results were analyzed using one-way ANOVA, followed by the Student-Newman-Keuls test. Data are reported as means $\pm S E$ and were analyzed using GraphPad PRISM, version 3.0 (GraphPad Software, USA). Differences with $P$ values $\leq 0.05$ were considered to be statistically significant.

\section{Results}

The effectiveness of the $T_{3}$ and PTU treatments was evaluated by determining the ratio of ventricular weight to body weight (VW/BW), DEO, and serum $\mathrm{T}_{4}$ concentration. Rats treated with $\mathrm{T}_{3}(4 \mu \mathrm{g} / 100 \mathrm{~g} \mathrm{BW}, \mathrm{sc})$ for 5,15 , and 30 days after $\mathrm{P} 1$ presented an increase in the VW/BW ratio, an earlier DEO, and decreased $\mathrm{T}_{4}$ levels, as expected. Rats treated with PTU (5 and $10 \mathrm{mg} / 100 \mathrm{~g} \mathrm{BW}$ ) showed a delay in the DEO and decreased serum $\mathrm{T}_{4}$ levels. These results are presented in Table 1 and confirmed the expected effects.

\section{Experiment I: evaluation of $\mathrm{Mb}$ gene expression in heart ventricle and skeletal muscles during rat postnatal development}

The pattern of Mb mRNA expression in heart ventricle and skeletal muscles of rats, from $\mathrm{P} 7$ through $\mathrm{P} 42$, is illustrated in Figure 1. Ventricle Mb mRNA content remained constant during the first 4 weeks of life, except on day P21, when a transitory increase was detected; then, a progressive increase in ventricular $\mathrm{Mb}$ mRNA expression occurred from days P35 to P42 (Figure 1A). In contrast, in the distal hind limb muscles, a gradual increase of $\mathrm{Mb}$ mRNA expression was observed from days P7 to P28, and remained unchanged up to day P42, when the Mb mRNA achieved a 12-times higher value than that observed at day P7 (Figure 1B).

\section{Experiment II: TH effect on heart ventricle and skeletal muscle Mb mRNA expression during the first 2 weeks of life}

Responsiveness of the $\mathrm{Mb}$ gene to $\mathrm{TH}$ was evaluated by determining $\mathrm{Mb}$ mRNA content in ventricle and skeletal muscles of rats treated for 5 days with increasing doses of $\mathrm{T}_{3}(0.5,1.0,1.5,2.0,4.0$, and $50 \mu \mathrm{g} / 100 \mathrm{~g} \mathrm{BW}$; doseresponse curve). Data from this experiment are summarized in Figure 2. No alteration in the ventricle muscle $\mathrm{Mb}$ mRNA expression was observed, even with the highest $T_{3}$ dose used (Figure 2A). However, extending $T_{3}$ treatment $(4 \mu \mathrm{g} / 100 \mathrm{~g} \mathrm{BW})$ to 15 days effectively increased the ventricle muscle $\mathrm{Mb}$ mRNA content (Figure $2 \mathrm{C}$ ). The 5and 15-day PTU treatment induced decreases in the ventricle muscle $\mathrm{Mb}$ mRNA content of $60 \%$ and $20 \%$, respectively (Figure $2 \mathrm{~B}$ and $\mathrm{C}$ ).

In contrast to heart ventricle muscle, the administration of increasing doses of $\mathrm{T}_{3}$ for 5 days raised the $\mathrm{Mb}$ mRNA expression in the skeletal muscle, which peaked at a $\mathrm{T}_{3}$ dose of $4 \mu \mathrm{g} / 100 \mathrm{~g} \mathrm{BW}$ (Figure 2D). At the highest $\mathrm{T}_{3}$ dose tested $(50 \mu \mathrm{g} / 100 \mathrm{~g} \mathrm{BW})$, a fall in the Mb mRNA expression was observed, even though the values obtained were still higher than those of the control group. Surprisingly, the 5-day PTU treatment with $5 \mathrm{mg} / 100 \mathrm{~g}$ BW led to an increase of Mb mRNA content in skeletal muscles (Figure 2E), followed by a decrease to control values when extending the treatment to day P15 (Figure $2 \mathrm{~F}$ ). When the PTU dose was increased 2-fold, the Mb mRNA content in the 5-day PTU treated rats decreased to the values seen in the control group (Figure $2 \mathrm{E}$ ). In spite of that, both PTU doses (5 and $10 \mathrm{mg} / 100 \mathrm{~g} \mathrm{BW}$ ) were able to induce hypothyroidism (Table 1).

\section{Experiment III: reprogramming of Mb gene expression in heart ventricle and skeletal muscles after induction of HyperPNT or HypoPNT}

The Mb mRNA content of ventricle, soleus, and EDL muscles from 90 day-old rats in the HyperPNT or HypoPNT groups is summarized in Figure 3. Increased $\mathrm{Mb}$ mRNA content was seen in the ventricle muscle of HyperPNT group adults but not in the HypoPNT group adults (Figure $3 \mathrm{~A}$ ). HyperPNT and HypoPNT did not alter soleus muscle $\mathrm{Mb}$ mRNA expression in adults (Figure $3 \mathrm{~B})$, however both treatments led to a decrease of 
Table 1. Effect of thyroid hormone on development of body weight, ventricular weight, VW/BW ratio, DEO, and serum $\mathrm{T}_{4}$ concentrations of $\mathrm{T}_{3^{-}}(4 \mu \mathrm{g} / 100 \mathrm{~g}, \mathrm{sc}$; hyperthyroid group) and PTU- (5 mg/100 g, sc; hypothyroid group) treated rats for 5 , 15, and 30 days.

\begin{tabular}{|c|c|c|c|}
\hline Parameters & $\begin{array}{l}\text { Control } \\
(n=6)\end{array}$ & $\begin{array}{l}\text { Hyperthyroid } \\
\quad(n=6)\end{array}$ & $\begin{array}{l}\text { Hypothyroid } \\
\quad(n=6)\end{array}$ \\
\hline \multicolumn{4}{|l|}{ BW (g) } \\
\hline 5 days & $15 \pm 1$ & $14 \pm 1$ & $14 \pm 1$ \\
\hline 15 days & $24 \pm 1$ & $23 \pm 2$ & $25 \pm 1$ \\
\hline 30 days & $87 \pm 3$ & $72 \pm 4^{\#}$ & $35 \pm 3^{\bullet}$ \\
\hline \multicolumn{4}{|l|}{ VW (mg) } \\
\hline 5 days & $90 \pm 4$ & $161 \pm 8^{\star}$ & $83 \pm 2$ \\
\hline 15 days & $107 \pm 10$ & $152 \pm 23^{*}$ & $83 \pm 7$ \\
\hline 30 days & $310 \pm 20$ & $480 \pm 20^{\circ}$ & $121 \pm 16^{\bullet}$ \\
\hline \multicolumn{4}{|c|}{ VW/BW (mg/g) } \\
\hline 5 days & $6.1 \pm 0.3$ & $11.8 \pm 0.3^{\star}$ & $6.1 \pm 0.2$ \\
\hline 15 days & $4.4 \pm 0.3$ & $6.8 \pm 0.5^{+}$ & $3.3 \pm 0.2^{*}$ \\
\hline 30 days & $3.6 \pm 0.1$ & $6.7 \pm 0.3^{+}$ & $3.4 \pm 0.1$ \\
\hline \multicolumn{4}{|l|}{$\mathrm{T}_{4}(\mathrm{ng} / \mathrm{mL})$} \\
\hline 5 days & $28 \pm 1$ & $14 \pm 1^{+}$ & $22 \pm 3^{*}$ \\
\hline 15 days & $66 \pm 3$ & $15 \pm 1^{+}$ & $14 \pm 1^{+}$ \\
\hline 30 days & $40 \pm 1$ & $14 \pm 2^{+}$ & $7 \pm 1^{+}$ \\
\hline \multicolumn{4}{|c|}{ DEO (postnatal days) } \\
\hline 5 days & - & - & - \\
\hline 15 days & 13 & 11 & 14 \\
\hline 30 days & 13 & 11 & 14 \\
\hline
\end{tabular}

Rats treated with vehicle $(0.9 \% \mathrm{NaCl})$ were used as control. Data are reported as means $\pm \mathrm{SE}$. BW: body weight; VW: ventricular weight; DEO: day of eye opening; $\mathrm{T}_{4}$ : thyroxine; $\mathrm{T}_{3}$ : triiodothyronine; $\mathrm{PTU}$ : propylthiouracil. ${ }^{*} \mathrm{P}<0.05$, ${ }^{\#} \mathrm{P} 0.01,{ }^{+} \mathrm{P}<0.001$ compared with control group (ANOVA).

expression in the EDL muscle (Figure 3C).

HyperPNT and HypoPNT effects on body and ventricular weight, serum T3 levels, HR and ABP in adulthood

The results from adult rats (day P90) in the HyperPNT and HypoPNT groups are summarized in Table 2. The only parameter affected by HypoPNT was a decrease in body weight. However, rats in the HyperPNT group showed reduced BW and VW, and a decreased HR in adulthood, whereas the ABP was not altered. Serum $\mathrm{T}_{3}$ levels in both groups remained similar to control rats, indicating that the morphological and functional alterations observed in the HyperPNT and HypoPNT group animals resulted from the impact of the experimental treatments carried out in the first 30 days of life.

\section{Discussion}

In this study, we have shown that: a) Mb gene
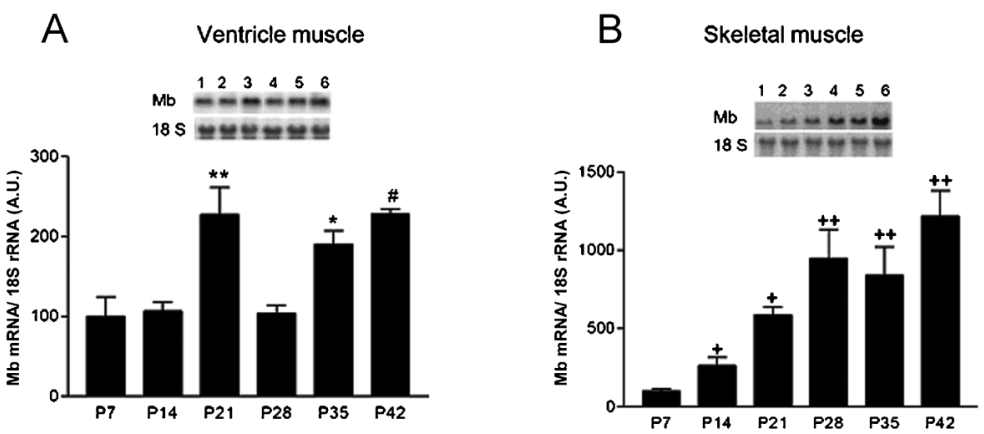

Figure 1. Pattern of Mb mRNA expression in ventricular and skeletal muscles of rats throughout the postnatal developmental period. Northern blot analysis of ventricular and skeletal Mb mRNA levels of intact rats from postnatal $(P)$ day 7 through P42 is shown at the top of the figure, and the quantitative results obtained by densitometric analysis of $\mathrm{Mb}$ and $18 \mathrm{~s}$ rRNA transcripts hybridization ratio are shown at the bottom, in arbitrary units (A.U.). Data are reported as means $\pm S E$ of 12 animals/group. ${ }^{*} \mathrm{P}<0.05$ and ${ }^{*} \mathrm{P}<0.01$ vs $\mathrm{P} 7$, $\mathrm{P} 14$, and $\mathrm{P} 28$; ${ }^{\mathrm{P}}<0.01$ vs all groups except $\mathrm{P} 21$; ${ }^{+} \mathrm{P}<0.01$ vs all groups; ${ }^{+}{ }^{+} \mathrm{P}<0.05$ vs $\mathrm{P} 7, \mathrm{P} 14$, and P21 (one-way ANOVA). 


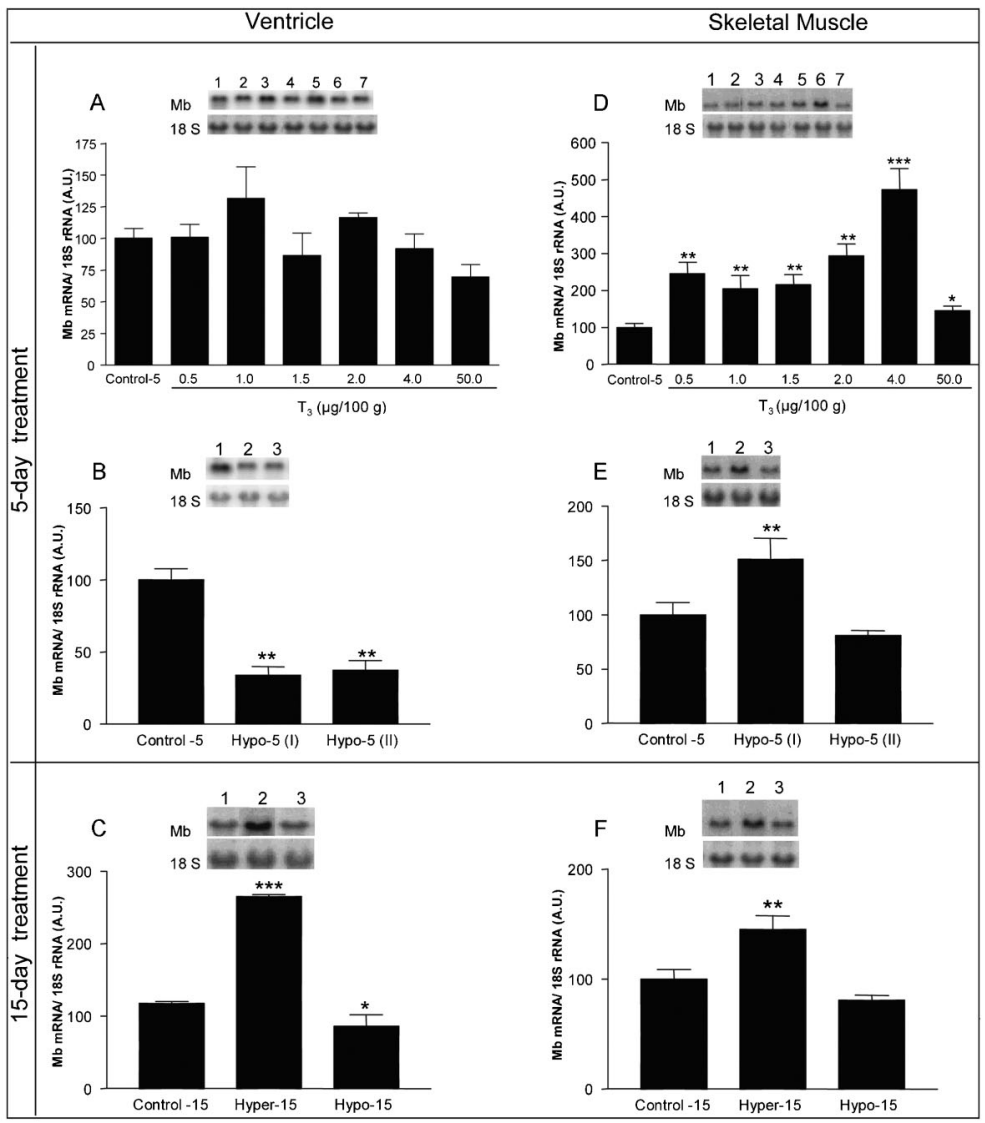

Figure 2. Influence of thyroid hormone on the pattern of $\mathrm{Mb}$ gene expression in ventricular and skeletal muscles of rats during 5 and 15 days of postnatal developmental. Northern blot analysis of ventricle and skeletal muscles $\mathrm{Mb}$ mRNA levels of rats subjected to $T_{3}$ or PTU treatment from $\mathrm{P} 0$ through $\mathrm{P} 5(A, B, D$, and $E)$ or $\mathrm{P} 15(C$ and $F)$ is shown at the top of each panel, and the quantitative results obtained by densitometric analysis of $\mathrm{Mb}$ and 18s rRNA transcripts hybridization ratio are shown at the bottom, in arbitrary units (A.U.). The effect of increasing doses of $\mathrm{T}_{3}$, from $\mathrm{PO}$ to $\mathrm{P} 5$, on $\mathrm{Mb}$ mRNA expression is shown in $A$ and $D$, and of the PTU treatment $[5 \mathrm{mg}=$ Hypo-5 (I), or $10 \mathrm{mg} / 100 \mathrm{~g}$ BW $=$ Hypo-5 (II)] during the same period, is shown in $B$ and $E$. Panels $C$ and $F$ show the effect of $\mathrm{T}_{3}(4 \mu \mathrm{g} / 100 \mathrm{~g} \mathrm{BW})$ and PTU ( $5 \mathrm{mg} / 100 \mathrm{~g} \mathrm{BW})$ treatment during the first 15 days of postnatal life on Mb mRNA expression. Data are reported as means $\pm \mathrm{SE}$ of 12 animals/group. ${ }^{*} \mathrm{P}<0.05,{ }^{* *} \mathrm{P}<0.01$ and ${ }^{* * *} \mathrm{P}<0.001$ vs control- 5 and vs control- 15 (oneway ANOVA). expression differed in heart ventricle and skeletal muscles during the postnatal period, b) $\mathrm{TH}$ effects on $\mathrm{Mb}$ gene expression were tissue- and age-dependent, c) induction of HyperPNT and HypoPNT altered Mb mRNA levels differently in the cardiac and skeletal muscles of adult rats, and d) transient HyperPNT induced a permanent decrease on VW and HR in adult life.

Compared to skeletal muscle, the heart exhibited a delayed postnatal increase in Mb mRNA expression and required a longer period of time to be affected by hyperthyroidism. The induction of hyperthyroidism led to reprogramming of $\mathrm{Mb}$ gene expression as indicated by the increased ventricular $\mathrm{Mb}$ mRNA content, and decreased heart rate and ventricle weight in adulthood.

The rat heart starts beating at embryonic day 9.5 (E9.5), whereas the generalized mass movements involving the head, neck, and forelimbs can be seen from E16 onwards. So, considering that muscle activity increases $\mathrm{Mb}$ gene expression, one may expect that the heart has a higher Mb mRNA content than skeletal muscle at birth and in the first days of the PN period. This implies that changes of $\mathrm{Mb}$ gene expression in the heart could be less evident than those observed in skeletal muscle during this period of development, as observed from the time-course studies (Figure 1). This observation accounts for the delayed postnatal increase of Mb mRNA expression in the heart when compared with skeletal muscles.

Skeletal muscles achieve the adult phenotype and functional characteristics (19) later than heart muscle. This is the reason that a muscle of the distal hind limb group was used in the time-course experiments and in the studies of Mb mRNA expression in 5- and 15-day-old rats (9). Hence, the Mb expression in skeletal muscle followed its developmental trend. In effect, a 5-fold increase in sarco/endoplasmic reticulum $\mathrm{Ca}^{2+}$-ATPase (SERCA) 1 level has been reported between days P5 and P20 (20), a period in which a significant increase of the $\mathrm{Mb}$ gene expression in skeletal muscle (Figure 1B) was also observed. This somehow indicates that muscle fiber differentiation is taking place. In fact, SERCA1 is predominantly expressed in type II (fast), whereas $\mathrm{Mb}$ is more abundant in type I (slow) muscle fibers (21).

Cardiac postnatal development is associated with changes in the expression of several genes, some of them coincident with the postnatal increase of $\mathrm{TH}$ levels and/or with their peak at the third week of life (22). In the first weeks of life, genes that encode the isoform 1 of the glucose transporter, sodium/calcium exchanger, beta 


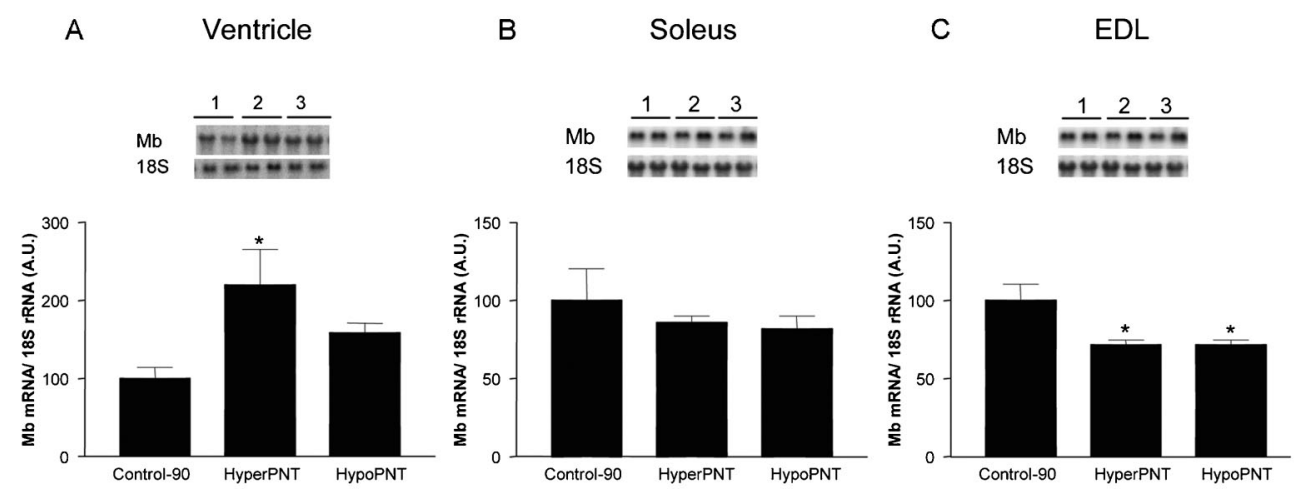

Figure 3. Effect of transient postnatal hyper- and hypothyroidism from postnatal $(\mathrm{P})$ day 0 to $\mathrm{P} 30$ on molecular programming of myoglobin gene expression in ventricle $(A)$, soleus $(B)$ and extensorum digitalis longus (EDL) $(C)$ muscles of 90 -day-old rats. Northern blot analysis of ventricle, soleus, and EDL Mb mRNA levels of rats subjected to vehicle (control-90), $T_{3}(4 \mu \mathrm{g} / 100 \mathrm{~g} \mathrm{BW}, \mathrm{HyperPNT})$ and PTU $(5 \mathrm{mg} / 100 \mathrm{~g} \mathrm{BW}$, HypoPNT) treatment from P0 through P30, and allowed to grow with no further treatment until 90 days of life, is shown at the top of each panel, and the quantitative results obtained by densitometric analysis of Mb and 18s rRNA transcripts hybridization ratio is shown at the bottom, in arbitrary units (A.U). Data are reported as means $\pm \mathrm{SE}$ of 12 animals/group. ${ }^{*} \mathrm{P}<0.05$ vs control-90 (ANOVA).

isoform of the myosin heavy chain and the $\beta 1$ isoform of the $\mathrm{TH}$ receptor have a decreased expression, in contrast to those genes that encode the isoform 4 of the glucose transporter, SERCA2, alpha myosin heavy chain and alpha isoform of thyroid receptor (17,23-25). These molecular changes alter glucose and intracellular calcium availability, the speed of muscle contraction, and there is evidence that the pattern of expression of these genes, which are known targets of $\mathrm{TH}$, can be influenced by the thyroid state $(26,27)$.

In fact, hyperthyroidism leads to a hyperkinetic heart state, which could be deleterious in the first stages of postnatal development (28). However, the heart shows tissue-specific regulation mechanisms for $\mathrm{TH}$ action in the postnatal period, such as increased expression of TR $\alpha 2$ (a non-ligand-binding $\mathrm{TH}$ receptor isoform) (29) and significant $\mathrm{TH}$ inactivation (30), which ensure its protection against the impact of $\mathrm{TH}$ in this period, even in the presence of increased $\mathrm{TH}$ levels.
The lack of ventricular $\mathrm{Mb}$ gene responsiveness to the progressive increase of $\mathrm{T}_{3}$ doses observed in 5-day-old rats, in contrast to the response of adult rats (9), supports this proposition. This response is similar to that reported for neonatal cardiomyocytes treated with growth hormone $(\mathrm{GH})$, which, unlike adult cardiomyocytes, are refractory to $\mathrm{GH}$ effects, because $\mathrm{GH}$ receptors are not functional in intrauterine and early postnatal life (31). In contrast, the skeletal muscle of 5-day-old rats exhibited increased $\mathrm{Mb}$ mRNA content in response to $T_{3}$, an effect that was greatest at $4 \mu \mathrm{g} \mathrm{T}_{3} / 100 \mathrm{~g} \mathrm{BW}$, a dose 12.5-fold smaller than the highest used in the study. Indeed, high doses of $\mathrm{T}_{3}$ induce protein catabolism, which might explain the strong response to a low $\mathrm{T}_{3}$ dose (32).

As no thyroid response element has been shown in the promoter region of the $\mathrm{Mb}$ gene, we postulate that tissue-specific factors might be involved in cardiac- and skeletal-muscle responsiveness to this hormone. This strengthens the possibility that the Mb gene may be

Table 2. Body weight, ventricular weight, $\mathrm{VW} / \mathrm{BW}$ ratio, serum $\mathrm{T}_{3}$, heart rate, and arterial blood pressure of rats treated with vehicle (control), $\mathrm{T}_{3}(4 \mu \mathrm{g} / 100 \mathrm{~g}, s c$; HyperPNT) or PTU (10 mg/100 g, sc; HypoPTN) for the first 30 days of life, and sacrificed at 90 days of life.

\begin{tabular}{lccc}
\hline Parameters & Control & HyperPNT & HypoPNT \\
\hline BW $(\mathrm{g})$ & $267 \pm 8$ & $211 \pm 7^{\#}$ & $230 \pm 14^{*}$ \\
VW $(\mathrm{mg})$ & $710 \pm 20$ & $530 \pm 20^{+}$ & $659 \pm 30$ \\
VW/BW $(\mathrm{mg} / \mathrm{g})$ & $2.6 \pm 0.1$ & $2.5 \pm 0.1$ & $2.8 \pm 0.1$ \\
$\mathrm{~T}_{3}(\mathrm{ng} / \mathrm{mL})$ & $0.29 \pm 0.03$ & $0.25 \pm 0.05$ & $0.30 \pm 0.05$ \\
HR $(\mathrm{bpm})$ & $410 \pm 5$ & $393 \pm 2^{*}$ & $404 \pm 2$ \\
ABP $(\mathrm{mmHg})$ & $126 \pm 2$ & $128 \pm 1$ & $133 \pm 3$ \\
\hline
\end{tabular}

Data are reported as means \pm SE of 3 independent experiments for 6-8 animals/group. BW: body weight; VW: ventricular weight; HR: heart rate; ABP: arterial blood pressure; $\mathrm{T}_{3}$ : triiodothyronine; $\mathrm{PTU}$ : propylthiouracil. ${ }^{*} \mathrm{P}<0.05,{ }^{\#} \mathrm{P}<0.01,{ }^{+} \mathrm{P}<0.001$ vs control group (ANOVA). 
indirectly activated by $\mathrm{T}_{3}$. Moreover, the effects of $\mathrm{TH}$ on $\mathrm{Mb}$ gene expression in early postnatal life are distinct from that in adult life, when hyperthyroidism increases Mb mRNA and protein levels in heart ventricle, soleus and EDL muscles $(8,9)$.

In neonate rats, the PTU-treatment for a 5-day period markedly decreased the ventricular Mb mRNA content, however, when the treatment was extended to 15 days, Mb mRNA was not significantly different from control values, indicating that adjustments had taken place to protect the heart against the hypothyroid status. Actually, $T_{3}$ is essential for several cyclical biochemical reactions and pathways needed for proper postnatal cardiac development. Supporting our assumption, rats treated for 15 days with PTU and reverse $T_{3}$, a competitive inhibitor of deiodinase II (D2) activity, exhibited a remarkable decrease in ventricular Mb mRNA content (data not shown). This finding demonstrates the critical role of $\mathrm{D} 2$ activity for the maintenance of the Mb mRNA expression in the heart. Thus, even decreased, the $T_{4}$ secreted by PTU-treated rats could provide enough $T_{3}$ to protect the heart from hypothyroidism, where D2 activity is highly increased (33). In fact, the presence of D2 has been demonstrated in human and rodent hearts (34).

Even more intriguing was the increase in skeletal muscle $\mathrm{Mb}$ mRNA levels in response to a 5-day PTU treatment with $5 \mathrm{mg} / 100 \mathrm{~g} \mathrm{BW}$. This may result from increased muscle contraction activity (shivering), triggered by a hypothyroidism-induced decrease in body temperature, which is known to enhance Mb gene expression. However, it is not clear if this thermoregulatory mechanism is involved in the control of neonate body temperature, in which generation of $T_{3}$ in response to increased $\mathrm{D} 2$ activity in brown adipose tissue is thought to be the main mechanism involved in thermogenesis (35). Nevertheless, in addition to the increased D2 activity observed in hypothyroid states and the high D2 expression in skeletal muscle, shivering could contribute to this finding. In contrast, a 2-fold increase in PTU dose led to severe hypothyroidism in the animals, with considerable loss of body weight and a hypokinetic state. Under these conditions $\mathrm{T}_{4}$ synthesis was almost completely blocked, preventing a substantial amount of $T_{3}$ generation from $T_{4}$ deiodination in brown adipose tissue, skeletal and cardiac muscles.

In effect, Mb gene control by $\mathrm{TH}$ is very complex, as shown by Brik and Shainberg in 1990 (27), who demonstrated decreased $\mathrm{Mb}$ gene expression in isolated cardiomyocytes by $T_{3}$ treatment. In the present study, $T_{3}$ treatment from days P0 to P5 did not induce any alteration in ventricular Mb mRNA. This response was abolished when the treatment was extended to 15 days, after which the effects of $T_{3}$ were similar to those observed in both ventricular and skeletal muscles of adult rats.

On the other hand, hyperthyroidism led to an increased expression of Mb mRNA in cardiac muscle, and both hyper- and hypothyroidism caused its decrease in EDL muscle in adulthood. These results corroborate previous studies that identified THs as important regulators of many gene programs (36), and similar to the $\mathrm{GH}$ gene program, as pointed out in our studies. The induction of hyperthyroidism at an early postnatal period led to a decreased $\mathrm{GH}$ expression in adulthood, with repercussions in body weight, lean fat and bone mass (37). Taking these considerations into account, we postulate that alterations in thyroid function during the early postnatal period lead to adjustments that allow the cardiac and skeletal muscles to develop properly, even in the presence of a challenge in the intracellular environment, such as those described in models in which the nutritional environment is modified.

The hyperthyroid state increases the tissue $\mathrm{O}_{2}$ demand, leading the heart to express more $\mathrm{Mb}$, as reported. Therefore, if hyperthyroidism is induced in early postnatal life, it could define a new pattern of gene expression in the heart, which is still immature, followed by an increase in ventricular Mb mRNA expression in adulthood, a period in which a decrease in the VW and in the HR was also detected. SERCA 2 mRNA expression (unpublished data) was also increased in these animals. Taken together, these results suggest that HyperPNT improved the oxidative potential of the adult heart and its ability to remove reactive oxygen species, leading to a gain in the cardiac function, considering that the heart became smaller and bradycardic. Taking these considerations into account we postulate that rat hearts subjected to HyperPNT seem to be more prepared to act in response to a higher cardiovascular demand.

In the EDL muscle, both HyperPNT and HypoPNT led to a decrease in Mb mRNA content. EDL is a highly glycolytic muscle, therefore, such alterations seem to cause minor repercussions in its function. In contrast, the oxidative soleus muscle was preserved from the $\mathrm{TH}$ reprogramming effect on the $\mathrm{Mb}$ gene, and this could be particularly important considering its postural role.

In conclusion, the results presented here showed that $\mathrm{Mb}$ gene expression and the responsiveness to $\mathrm{TH}$ during postnatal development are tissue- and age-dependent, and indicated $\mathrm{TH}$ as a potential early programming agent of $\mathrm{Mb}$ mRNA expression in heart ventricle and skeletal muscles. The permanent decrease observed in the heart rate also reveals that HyperPNT led to repercussions in cardiovascular function, which might improve its responsiveness to increased cardiovascular demand.

\section{Acknowledgments}

Research supported by FAPESP (\#2000/08755-0), CNPq (\#301483/2006-0) and FUNDECT (\#0248/12). 


\section{References}

1. Yamada $T$, Furuichi $\mathrm{Y}$, Takakura $\mathrm{H}$, Hashimoto $\mathrm{T}$, Hanai $\mathrm{Y}$, Jue $\mathrm{T}$, et al. Interaction between myoglobin and mitochondria in rat skeletal muscle. J Appl Physiol 2013; 114: 490497, doi: 10.1152/japplphysiol.00789.2012.

2. Storz JF, Opazo JC, Hoffmann FG. Gene duplication, genome duplication, and the functional diversification of vertebrate globins. Mol Phylogenet Evol 2013; 66: 469-478, doi: 10.1016/j.ympev.2012.07.013.

3. Wittenberg JB, Wittenberg BA. Myoglobin function reassessed. J Exp Biol 2003; 206: 2011-2020, doi: 10.1242/ jeb.00243.

4. Kreutzer U, Jue T. Investigation of bioactive NO-scavenging role of myoglobin in myocardium. Pflugers Arch 2006; 452: 36-42, doi: 10.1007/s00424-005-0011-z.

5. Flogel U, Laussmann T, Godecke A, Abanador N, Schafers $M$, Fingas $C D$, et al. Lack of myoglobin causes a switch in cardiac substrate selection. Circ Res 2005; 96: e68-e75, doi: 10.1161/01.RES.0000165481.36288.d2.

6. Schlieper G, Kim JH, Molojavyi A, Jacoby C, Laussmann T, Flogel U, et al. Adaptation of the myoglobin knockout mouse to hypoxic stress. Am J Physiol Regul Integr Comp Physiol 2004; 286: R786-R792, doi: 10.1152/ajpregu.00043.2003.

7. Meeson AP, Radford N, Shelton JM, Mammen PP, DiMaio JM, Hutcheson K, et al. Adaptive mechanisms that preserve cardiac function in mice without myoglobin. Circ Res 2001; 88: 713-720, doi: 10.1161/hh0701.089753.

8. dos Santos RA, Giannocco G, Nunes MT. Thyroid hormone stimulates myoglobin expression in soleus and extensorum digitalis longus muscles of rats: concomitant alterations in the activities of Krebs cycle oxidative enzymes. Thyroid 2001; 11: 545-550, doi: 10.1089/105072501750302840.

9. Giannocco G, DosSantos RA, Nunes MT. Thyroid hormone stimulates myoglobin gene expression in rat cardiac muscle. Mol Cell Endocrinol 2004; 226: 19-26, doi: 10.1016/j.mce. 2004.07.007.

10. Garry DJ, Bassel-Duby RS, Richardson JA, Grayson J, Neufer PD, Williams RS. Postnatal development and plasticity of specialized muscle fiber characteristics in the hindlimb. Dev Genet 1996; 19: 146-156, doi: 10.1002/ (SICI)1520-6408(1996)19:2<146::AID-DVG6>3.0.CO;2-9.

11. Adams GR, McCue SA, Zeng M, Baldwin KM. Time course of myosin heavy chain transitions in neonatal rats: importance of innervation and thyroid state. Am J Physiol 1999; 276: R954-R961.

12. Koban MU, Moorman AF, Holtz J, Yacoub MH, Boheler KR. Expressional analysis of the cardiac $\mathrm{Na}-\mathrm{Ca}$ exchanger in rat development and senescence. Cardiovasc Res 1998; 37: 405-423, doi: 10.1016/S0008-6363(97)00276-9.

13. Postic C, Leturque A, Printz RL, Maulard P, Loizeau M, Granner DK, et al. Development and regulation of glucose transporter and hexokinase expression in rat. Am J Physiol 1994; 266: E548-E559.

14. Chanoine JP, Veronikis I, Alex S, Stone S, Fang SL, Leonard $\mathrm{JL}$, et al. The postnatal serum 3,5,3'-triiodothyronine (T3) surge in the rat is largely independent of extrathyroidal $5^{\prime}$ deiodination of thyroxine to T3. Endocrinology 1993; 133: 2604-2609.

15. de Moura EG, Passos MC. Neonatal programming of body weight regulation and energetic metabolism. Biosci Rep
2005; 25: 251-269, doi: 10.1007/s10540-005-2888-3.

16. Dillmann WH, Berry S, Alexander NM. A physiological dose of triiodothyronine normalizes cardiac myosin adenosine triphosphatase activity and changes myosin isoenzyme distribution in semistarved rats. Endocrinology 1983; 112: 2081-2087, doi: 10.1210/endo-112-6-2081.

17. Cernohorsky J, Kolar F, Pelouch V, Korecky B, Vetter R. Thyroid control of sarcolemmal $\mathrm{Na}^{+} / \mathrm{Ca}^{2+}$ exchanger and SR $\mathrm{Ca}^{2+}$-ATPase in developing rat heart. Am J Physiol 1998; 275: H264-H273.

18. O'Connor JC, Frame SR, Davis LG, Cook JC. Detection of thyroid toxicants in a tier I screening battery and alterations in thyroid endpoints over 28 days of exposure. Toxicol Sci 1999; 51: 54-70, doi: 10.1093/toxsci/51.1.54.

19. Punkt K, Naupert A, Asmussen G. Differentiation of rat skeletal muscle fibres during development and ageing. Acta Histochem 2004; 106: 145-154, doi: 10.1016/j.acthis. 2003.11.005.

20. van der Linden GC, Simonides WS, van Hardeveld C. Thyroid hormone regulates $\mathrm{Ca}\left({ }^{2+}\right)$-ATPase mRNA levels of sarcoplasmic reticulum during neonatal development of fast skeletal muscle. Mol Cell Endocrinol 1992; 90: 125-131, doi: 10.1016/0303-7207(92)90110-R.

21. Oh M, Rybkin II, Copeland V, Czubryt MP, Shelton JM, van Rooij E, et al. Calcineurin is necessary for the maintenance but not embryonic development of slow muscle fibers. $\mathrm{Mol}$ Cell Biol 2005; 25: 6629-6638, doi: 10.1128/MCB.25.15. 6629-6638.2005.

22. Vigouroux E. Dynamic study of post-natal thyroid function in the rat. Acta Endocrinol 1976; 83: 752-762.

23. Santalucia T, Camps M, Castello A, Munoz P, Nuel A, Testar $X$, et al. Developmental regulation of GLUT-1 (erythroid/Hep G2) and GLUT-4 (muscle/fat) glucose transporter expression in rat heart, skeletal muscle, and brown adipose tissue. Endocrinology 1992; 130: 837-846.

24. van Tuyl M, Blommaart PE, de Boer PA, Wert SE, Ruijter $\mathrm{JM}$, Islam $\mathrm{S}$, et al. Prenatal exposure to thyroid hormone is necessary for normal postnatal development of murine heart and lungs. Dev Biol 2004; 272: 104-117, doi: 10.1016/ j.ydbio.2004.03.042.

25. Fisher DJ, Towbin J. Maturation of the heart. Clin Perinatol 1988; 15: 421-446.

26. Castello A, Rodriguez-Manzaneque JC, Camps M, PerezCastillo A, Testar X, Palacin M, et al. Perinatal hypothyroidism impairs the normal transition of GLUT4 and GLUT1 glucose transporters from fetal to neonatal levels in heart and brown adipose tissue. Evidence for tissue-specific regulation of GLUT4 expression by thyroid hormone. $J$ Biol Chem 1994; 269: 5905-5912.

27. Brik $H$, Shainberg A. Thyroxine induces transition of red towards white muscle in cultured heart cells. Basic Res Cardiol 1990; 85: 237-246, doi: 10.1007/BF01907112.

28. Maragliano G, Zuppa AA, Florio MG, Scapillati ME, Girlando $P$, Crescimbini $B$, et al. Efficacy of oral iodide therapy on neonatal hyperthyroidism caused by maternal Graves' disease. Fetal Diagn Ther 2000; 15: 122-126, doi: 10. 1159/000020989.

29. White P, Dauncey MJ. Differential expression of thyroid hormone receptor isoforms is strikingly related to cardiac 
and skeletal muscle phenotype during postnatal development. J Mol Endocrinol 1999; 23: 241-254, doi: 10.1677/ jme.0.0230241.

30. van der Heide SM, Joosten BJ, Dragt BS, Everts ME, Klaren $\mathrm{PH}$. A physiological role for glucuronidated thyroid hormones: preferential uptake by H9c2(2-1) myotubes. Mol Cell Endocrinol 2007; 264: 109-117, doi: 10.1016/j.mce. 2006.10.012.

31. Lu C, Schwartzbauer G, Sperling MA, Devaskar SU, Thamotharan S, Robbins PD, et al. Demonstration of direct effects of growth hormone on neonatal cardiomyocytes. J Biol Chem 2001; 276: 22892-22900, doi: 10.1074/ jbc.M011647200.

32. Brown JG, Millward DJ. Dose response of protein turnover in rat skeletal muscle to triiodothyronine treatment. Biochim Biophys Acta 1983; 757: 182-190, doi: 10.1016/03044165(83)90107-1.

33. Marsili A, Tang D, Harney JW, Singh P, Zavacki AM, Dentice M, et al. Type II iodothyronine deiodinase provides intracellular 3,5,3'-triiodothyronine to normal and regenerating mouse skeletal muscle. Am J Physiol Endocrinol Metab
2011; 301: E818-E824, doi: 10.1152/ajpendo.00292.2011.

34. Dentice M, Morisco C, Vitale M, Rossi G, Fenzi G, Salvatore $D$. The different cardiac expression of the type 2 iodothyronine deiodinase gene between human and rat is related to the differential response of the Dio2 genes to Nkx-2.5 and GATA-4 transcription factors. Mol Endocrinol 2003; 17 1508-1521, doi: 10.1210/me.2002-0348.

35. Wu SY, Merryfield ML, Polk DH, Fisher DA. Two pathways for thyroxine $5^{\prime}$-monodeiodination in brown adipose tissue in fetal sheep: ontogenesis and divergent responses to hypothyroidism and 3,5,3'-triiodothyronine replacement. Endocrinology 1990; 126: 1950-1958, doi: 10.1210/endo126-4-1950.

36. Walker $P$. Increased pituitary thyroxine $5^{\prime}$-deiodinase activity in adult rats rendered hyper- or hypo-thyroid during perinatal life. Can J Physiol Pharmacol 1985; 63: 279-282, doi: 10.1139/y85-050.

37. de Picoli Souza K, Silva FG, Nunes MT. Effect of neonatal hyperthyroidism on $\mathrm{GH}$ gene expression reprogramming and physiological repercussions in rat adulthood. $J$ Endocrinol 2006; 190: 407-414, doi: 10.1677/joe.1.06371. 